\title{
Perbedaan Antara Jumlah Sel T Subset Gamma-Delta di Darah Tepi pada Penderita Tuberkulosis dan Orang dengan Latent Tuberculosis Infection
}

\author{
RYZKY WIDI ATMAJA, JUSAK NUGRAHA \\ Program Studi S2 Imunologi, Sekolah Pascasarjana Universitas Airlangga \\ Jl. Airlangga no. 4-6 Surabaya, Jawa Timur, Telp. (031)5914042 \\ ryzky_widi@yahoo.com, jusak.nugraha@yahoo.com
}

\begin{abstract}
Abstrak
Latar Belakang. Imunitas memiliki peranan penting untuk melindungi host dari bacilli Mycobacterium tuberculosis (M.tb), bakteri Obligat intraseluler yang menyebabkan Tuberkulosis (TB) dan latent tuberculosis infection (LTBI). Sel T subset gamma-delta (T$\gamma \delta$ ) adalah sel-sel potensial tersembunyi yang bermain peran di imunitas innate dan adaptive pada TB. Tetapi, hingga kini perananya di LTBI masih menjadi misteri. Bahan dan Metode. Penelitian dilakukan dengan melibatkan 10 penderita TB serta 10 orang dengan LTBI. Mereka didapatkan dari Rumah Sakit Paru Surabaya melalui suatu persetujuan kelaikan etik dari Universitas Airlangga. Sampel-sampel tersebut akan dihitung jumlah sel T- $\gamma \delta$ menggunakan F A C S C a 1 i b u r. Hasil. Jumlah sel T- $\gamma \delta$ meningkat pada TB $(10,7 \%)$ dan LTBI $(15,4 \%)$. Jumlah dari kedua kelompok tersebut melebihi rerata normal di darah tepi $(1 \%-5 \%)$. Kesimpulan. Penigkatan jumlah sel $\mathrm{T}-\gamma \delta$ pada TB disebabkan melimpahnya kadar IL-12 yang dilepas oleh makrofag selama infeksi. Sementara, peningkatan jumlah sel T- $\gamma \delta$ pada LTBI diasumsikan karena banyaknya heat shock protein (HSPs) yang dilepas oleh M.tb di bawah kondisi stres.

Kata kunci: tuberkulosis, latent tuberculosis infection, Mycobacterium tuberclosis, sel $\mathrm{T}$ subset gamma-d e $1 \mathrm{t}$ a.
\end{abstract}

\section{Abstract}

Background. Immunity has a crucial role to protect the host from bacilly Mycobacterium tuberculosis (M.tb), an obligate intracellular bacteria that cause tuberculosis (TB) and latent tuberculosis infection (LTBI). Gamma-d e l t a $(\gamma \delta)$ T cells are hidden potential cells playing a role in innate and adaptive immunity to TB. However, the role of those cells in LTBI is still become a mystery for now. Material and Method. 10 patients with TB and 10 people with LTBI were performed in this research study. They were obtained in Rumah Sakit Paru Surabaya by ethical clearance approval from Airlangga University. The samples that had been preparated would be measured by $F$ A C S C a l i b u r. Result. The proportion of $\gamma \delta T$ cells increased in $T B(10,7 \%)$ then highly increased in LTBI (15,4\%). the proportion from two groups was greater than normal ranges (1\%-5\%) in the peripheral blood of healthy human measured Conclusion. The increasing of $\gamma \delta T$ cells in $T B$ caused by abundant of IL-12 concentrate that released by macrophages during early infection. In the other hand, the event of the increasing of $\gamma \delta T$ cells in LTBI it assumed it caused by heat shock proteins (HSPS) that released by M.tb under stress condition in LTBI.

Keywords: tuberculosis, latent tuberculosis infection, Mycobacterium tuberculosis, gammadelta $T$ cells subset. 


\section{Pendahuluan}

Tuberkulosis (TB) masih menjadi masalah kesehatan utama global yang menduduki peringkat kedua sebagai penyakit infeksi yang menyebabkan kematian setelah human immunodeficiency virus $(H I V)$. Sepertiga penduduk di dunia terinfeksi oleh Mycobacterium tuberclosis (M.tb), tetapi sebagian besar (90\%-95\%) dari mereka tetap sehat tanpa menunjukkan suatu gejala. Kondisi tersebut disebut latent tuberculosis infection (LTBI). Imunitas host menjadi salah satu faktor penting dalam status kelatentan LTBI (Dyrhol-Riise et al., 2010 ).

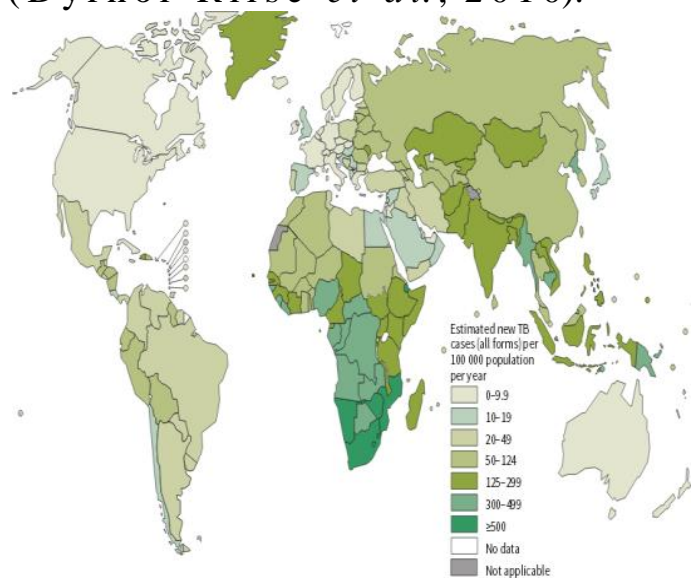

Gambar 1.1. Perkiraan insiden TB di seluruh dunia (WHO., 2015)

Pada kebanyakan orang, infeksi perdana M.tb merangsang perkembangan respons seluler spesifik yang menghambat pertumbuhan mikobakteria tersebut, tetapi tidak mampu membunuhnya. Pada kebanyakan orang juga, M.tb persisten di dalam kondisi dorman yang akhirnya menjadi suatu kondisi laten atau latent tuberculosis infection (LTBI). Pada umumnya, respons seluler selalu berpusat di sel Th1, dari sel tersebut melibatkan banyak komponen dalam pertahanan melawan M.tb, misalnya sel imun, antara lain makrofag, sel dendrit, sel Tc, dan sel NK, sitokin proinflamasi, antara lain IFN- $\gamma$, IL-1, IL-2, IL-12, dan IL-18, dan kemokin, antara lain IL-8, dan macrophage chemoattractant protein-1 (MCP1). Keseluruhan komponen tersebut berakhir kepada terbentuknya granuloma yang berfungsi membentengi makrofag terinfeksi oleh M.tb agar tidak menginfeksi sel-sel lainnya yang menyebabkan timbulnya penyakit aktif (Dye et al., 1999. Co et al., 2004).

Imunitas protektif melawan M.tb adalah hasil interaksi antara antigenpresenting cells (APCs) teraktivasi dan selsel $\mathrm{T}$ spesifik. Sel $\mathrm{T}$ subset gamma-delta $(\mathrm{T}-\gamma \delta)$ adalah salah satu limfosit innate yang berperan penting dalam pertahanan melawan M.tb. Hal tersebut tidak terlepas dari fungsinya yang mampu mengenali epitop native dan ligan-ligan besar, mampu bereaksi cepat tanpa memerlukan sensitisasi, dan mampu 'meniru' fungsi sel-sel imun lain (gertner et al, 2007. Meraviglia et al., 2010 ). Telah diketahui bahwa sel T- $\gamma \delta$ menjadi sel penghubung antara imunitas innate dan adaptive dengan cara menjadi sel efektor yang menghasilkan sitokin-sitokin proinflamasi, misalnya IFN- $\gamma$, IL-4, dan IL-17. Peng et al melalui penelitiannya juga telah membuktikan bahwa sel $\mathrm{T}-\gamma \delta$ menjadi penghasil utama IFN- $\gamma$ dan IL-17 pada penderita TB. Hal tersebut terbukti berdasarkan adanya peningkatan jumlah sel $\mathrm{T}-\gamma \delta$ yang memproduksi IFN- $\gamma$ dan IL-17 pada penderita TB. Tetapi, pada LTBI hingga kini belum ditemukan adanya penelitian yang serupa.

\section{Tinjauan Pustaka}

\subsection{Tuberkulosis}

Tuberkulosis (TB) adalah penyakit infeksi yang disebabkan oleh bacillus Mycobacterium tuberculosis (M.tb). Bakteri intraseluler tersebut menginfeksi makrofag, utamanya makrofag alveolar. Mereka memakai berbagai reseptor bernama pattern-recognition receptors (PRRs) untuk masuk ke dalam makrofag. Dari berbagai jenis PRRs, toll-like receptors (TLRs) adalah reseptor yang paling sering dipakai oleh M.tb (A k a g a w a., 2012. Kaufmann et al., 2014). M.tb berada di dalam fagosom segera setelah masuk ke dalam makrofag, lalu diikuti oleh fusi antara fagosom dan 
lisosom membentuk fagolisosom. M.tb memakai salah satu faktor virulensinya yaitu mannose-capped lipoarabinomannan (ManLAM) untuk mengubah serta merusak komposisi dinding fagosom sehingga Fusi fagosom dan lisosom membentuk fagolisosom dapat dihambat. Selain melalui ManLAM, M.tb mampu bertahan di dalam fagolisosom dengan cara menghambat produksi dua mekanisme antimikobakteria, yaitu reactive nitrogen intermediate $(R N I)$ dan reactive oxygen intermediate (ROI) (Voskuil et al., 2003. Briken et al., 2004).

Respons imun melawan bakteri, misalnya M.tb melibatkan banyak komponen, seperti PRRs, sitokin dan kemokin, hingga sel-sel imun. Dalam komponen PRRs, ada TLR2 yang menjadi reseptor utama yang sering dipakai oleh A.tb unttk mastk ke dalam makrofag. TLR2 mengenali lipomannan, lipoarabinomannan, phosphatidylinositolmannoside, dan lipoprotein dicaylated (TLR2/TLR1) atau lipoprotein triacylated (TLR2/TLR6). Reseptor tersebut menjadi penting karena mengawali respons imun innate (Means et al., 1999. Kawai and Akira., 2010). Dalam komponen sitokin, ada IFN- $\gamma$ yang menjadi sitokin kunci dalam respons imun melawan M.tb. IFN- $\gamma$ yang bersinergi dengan TNFa dapat mengaktivasi makrofag dan meningkatkan produksi RNI dan ROI. Dari kelarga interleukin, IL-12 adalah sitokin yang berperan paling penting. Sitokin yang diproduksi oleh makrofag dan sel dendrit tersebut dapat merangsang sel imun lain yang mampu memproduksi IFN- $\gamma$, misalnya sel Th1, sel $\mathrm{T}-\gamma \delta$, bahkan makrofag itu sendiri. Karena kemampuan yang dapat merangsang respons sel Th1, IL-12 sering dijadikan adjuvan pada vaksin (FUjiwara et al., 1986. FLynn et al., 1993).

$\begin{array}{ll}\text { Reseptor } & \text { Contoh } \\ \text { CD14 } & - \\ \text { C-type lectin } & \text { DC-SIGN, dectin-1, mincle } \\ \text { C-type lectin (soluble) } & \text { MBL } \\ \text { NLRs } & \text { NOD1, NOD2 } \\ \text { Reseptor Fc } & \text { Fc } \gamma R \\ \text { Reseptor komplemen } & \text { CR1, CR3, CR4 }\end{array}$

$\begin{array}{ll}\text { Reseptor scavenger } & \text { CD36 } \\ \text { TLRs } & \text { TLR2, TLR4, TLR8, TLR9 }\end{array}$

Tabel 2.1. Reseptor yang dipakai oleh M.tb (Atmaja., 2016)

Selain mekanisme penghambatan fusi antara fagosom dan lisosom, M.tb masih memiliki cara lain apabila mereka gagal melakukan mekanisme survival sehingga fagolisosom berhasil dibentuk. Mereka memiliki dua protein sekretori potensial, yaitu 6-kDa early secreted antigeni target (ESAT-6) dan 10-kDa culture filtrate protein (CFP-10). Ketika di dalam fagosom, di bawah kondisi asidifikasi, ESAT-6 dan CFP-10 dilepas oleh M.tb, tetapi hanya ESAT-6 yang berhasil menyusup ke lapisan lipid bilayer sehingga menyebabkan lisisnya fagosom dan M.tb pun dapat keluar. Selain itu, fungsi ESAT-6 yang lain adalah mampu merangsang apoptosis makrofag melalui jalur ekstrinsik (caspase-dependent), menyebabkan sitolisis sel epitel alveolar tipe I dan II (pneumocytes) sehingga M.tb dapat menyebar melalui dinding alveolar, dan mampu menekan respons sitokin proinflamasi yang diproduksi oleh makrofag sehingga mereka dapat menginfeksi sel-sel lain disekitarnya (Derrik and Morris., 2007. Kinhikar et al., 2010).

Dalam komponen sel imun, makrofag menjadi sel pusat dalam respons imun melawan M.tb. Sel tersebut menjadi tempat replikasi bagi bakteri selama infeksi awal dan tempat bernaung bagi bakteri persisten di dalam granuloma selama infeksi kronis. Meskipun terinfeksi oleh M.tb, makrofag masih dapat berperan memproduksi IL-1, IL-12, dan TNF $\alpha$ karena pada umumnya IFN- $\gamma$ dihambat oleh M.tb (Kawai and Akira., 2010). Selain makrofag, neutrofil adalah sel imun yang bergerak cepat saat terjadi infeksi. Serupa dengan makrofag, neutrofil mampu melakukan fagositosis ditambah kemampuannya memproduksi granula-granula antimikroba yang tidak dimiliki oleh makrofag. Neutrofil juga dapat berperan dalam melakukan perondaan atau immunosurveillance. Sel 
NK adalah salah satu limfosit innate yang memiliki fungsi sitotoksik, tetapi perannya dalam respons imun TB belum banyak diketahui. Selain itu, uniknya sel NK mampu membunuh sel Treg yang berpotensi merusak respons imun melawan M.tb (Ogata et al., 1992. Hartmann et al., 2001. junqueira-kipnis et al., 2003).

Sel dendrit menjadi menjadi sel yang menjembatani antara imunitas innate dan adaptive karena berperan menyajikan antigen serta berinteraksi langsung dalam mengawali imunitas adaptive yang diperantarai oleh sel T. Tetapi, terkadang M.tb menjadikan sel dendrit sebagai sel pasif dengan ikatan antara ManLAM dan DC-SIGN yang akan produksi sitokin antiinflamasi IL-10 (Hanekom et al., 2003). Di imunitas adaptive jumlah sel Th1 dan sel Tc meningkat pada TB. Sel Th1 berperan dalam memproduksi IL-2, IFN- $\gamma$, dan TNF $\alpha$, mengaktivasi makrofag, merangsang apoptosis makrofag melalui ikatan antara Fas dan FasL, serta mengendalikan infeksi di granuloma. Sementara, sel Tc berperan sebagai sel pembunuh langsung melalui granulysin dan mampu mengatur keseimbangan sel Th1 dan sel Th2 sebagai sel Treg melalui IFN- $\gamma$ pada sel Th1 dan IL-4 pada sel Th2 (Serbina et al., 2001. Chan and Flynn., 2004).

\subsection{Latent Tuberculosis Infection}

Latent tuberculosis infection (LTBI) pertama kali diutarakan oleh Clemens von Pirquet, dimana menjelaskan tentang seseorang yang memiliki reaksi positif terhadap uji tuberkulin, tetapi tidak memiliki gejala TB. LTBI sendiri tidak menginfeksi dan secara radiografis tidak menunjukkan adanya abnormalitas maupun tanda-tanda kesembuhan (Wagner., 1964). LTBI dapat berkembang menjadi penyakit TB dalam beberapa tahun atau dekade setelah infeksi perdana. Beberapa faktor resiko reaktivasi LTBI yang patut diwaspadai antara lain pengobatan imunosupresi (misalnya gluokortikoid, dan transplantasi), malnutrisi, merokok, alkoholisme, keganasan, diabetes insulin- dependent, kegagalan ginjal, dan infeksi HIV. Saat LTBI, M.tb berada dalam kondisi dorman sehingga tidak terdeteksi oleh sistem imun host (Stefan et al., 2010. Gideon and FLynn., 2011).

Cell-mediated immunity (CMI) adalah komponen utama dalam respons imun pada TB dan LTBI, salah satnya adalah makrofag. Makrofag yang terinfeksi oleh M.tb akan bermigrasi ke jaringan dimana banyak terdapat sel-sel imun untuk membentuk suatu granuloma. Granloma sejatinya adalah sekelompok sel imun yang telah mati dan menjadi dinding bagi makrofag terinfeksi. Makrofag terinfeksi itu sendiri akan berubah menjadi sel epiteloid tanpa kemampuan fagositosis atau fusi dengan sesama makrofag membentuk sel raksasa berinti banyak berbentuk menyerupai sabun yang dikenal sebagai foamy macrophage. Makrofag jenis tersebut menyediakan nutrisi yang cukup untuk M.tb persisten dalam fase LTBI. Apabila nutrisi tersebut habis, maka M.tb akan mengalami kondisi stres yang direspons dengan melepaskan suatu protein yaitu heat shock proteins (HSPs). Tetapi, hingga kini belum diketahui apakah bakteri tersebut di dalam makrofag atau dalam kondisi bebas di dalam jaringan granuloma saat melepas HSPs (Grosset., 2003. Peyron et al., 2008).

Karena LTBI tidak menunjukkan adanya gejalan maupun tanda-tanda klinis, maka untuk mendeteksinya digunakan suatu penanda imunologis dari respons imun. Dua metode yang sering digunakan adalah uji tuberkulin atau uji Mantoux dan interferon-gamma release assay (IGRA). Hingga tahun 2001, uji tuberkulin adalah metode tunggal dalam mendeteksi LTBI. Tuberkulin adalah suatu ekstrak gliserol dari mikobakteria dan purified protein derivative (PPD) adalah antigen-antigen spesifik non-spesies yang didapatkan dari filtrat pada kultur mikobakteria. Uji tuberkulin memerlukan waktu 48 jam-72 jam untuk mendeteksi LTBI. Hal tersebut karena uji tuberkulin memakai reaksi delayed-type hypersensitivity (DTH) 
sehingga memerlukan waktu sangat lama. Meskipun uji tuberkulin telah digunakan secara luas, tetapi memiliki kelemahan berupa kurangnya spesifisitas karena PPD berisi lebih dari 200 jenis antigen, dimana tidak spesifik terhadap $M t b$ dan ada hampir di semua strain mikobakteria (Gideon and Flynn., 2011. DRuszczynska et al., 2012).

Dua protein virulen yang dimiliki oleh M.tb, yaitu ESAT-6 dan CFP-10 adalah perangsang kuat untuk produksi IFN- $\gamma$. Kombinasi keduanya juga lebih spesifik daripada PPD untuk diagnosis infeksi M.tb. Karena kekuatan antigenesitas ESAT-6 dan CFP-10 itulah yang menjadi dasar perkembangan IGRA. IGRA adalah serangkaian uji diagnostik yang mengukur IFN- $\gamma$ yang diproduksi oleh selsel T spesifik M.tb. Di pasaran, ada tiga jenis IGRA, yaitu QuantiFERON-TB Gold, QuantiFERON-TB Gold In-Tube, dan T-SPOT TB. QuantiFERON-TB Gold berisi dua antigen $M$.tb, yaitu ESAT-6 dan CFP-10. QuantiFERON-TB Gold InTube menggunakan tiga peptida yang dicampur, yaitu ESAT-6, CFP-10, dan TB7.7. T-SPOT TB adalah suatu tipe dari enzyme-linked immunospot (ELISPOT) yang mengukur jumlah sel $\mathrm{T}$ yang memproduksi IFN- $\gamma$ setelah dirangsang oleh ESAT-6 dan CFP-10. Seiring waktu, hanya dua jenis yang memiliki akurasi tinggi, yaitu QuantiFERON-TB In-Tube dan T-SPOT TB.

\begin{tabular}{|c|c|c|c|}
\hline & $\begin{array}{c}\text { Uji tuber- } \\
\text { kulin }\end{array}$ & $\begin{array}{c}\text { Quanti } \\
\text { FERON-TB } \\
\text { In-Tube }\end{array}$ & T-SPOT TB \\
\hline $\begin{array}{c}\text { Digunakan } \\
\text { untuk }\end{array}$ & LTBI & LTBI & LTBI \\
\hline Pengamatan & In-vivo & Ex-vivo & Ex-vivo \\
\hline Teknik & Tusuk kulit & ELISA & ELISPOT \\
\hline $\begin{array}{c}\text { Antigen yang } \\
\text { digunakan }\end{array}$ & PPD & $\begin{array}{c}\text { ESAT-6 } \\
\text { CFP-10 } \\
\text { TB 7.7 }\end{array}$ & $\begin{array}{c}\text { ESAT-6 } \\
\text { CFP-10 }\end{array}$ \\
\hline $\begin{array}{c}\text { Hasil } \\
\text { dilaporkan }\end{array}$ & $\begin{array}{c}\text { Indurasi } \\
\text { kulit }\end{array}$ & Kadar IFN- $\gamma$ & Jumlah spot \\
\hline $\begin{array}{c}\text { Interpretasi } \\
\text { hasil }\end{array}$ & Subyektif & Obyektif & Obyektif \\
\hline Waktu & $\begin{array}{c}48 \text { jam } \\
\text { T2 jam }\end{array}$ & 24 jam & 24 jam \\
\hline Kunjungan & Dua kali & Sekali & Sekali \\
\hline $\begin{array}{c}\text { Pengaruh } \\
\text { vaksin BCG }\end{array}$ & Ya & Tidak & Tidak \\
\hline Reaksi silang & Ya & Jarang & Tidak \\
\hline
\end{tabular}

\begin{tabular}{|c|c|c|c|}
\hline & & (M. fortuitum) & \\
\hline Efek samping & Jarang & Tidak & Tidak \\
\hline Efek booster & Ya & Tidak & Tidak \\
\hline
\end{tabular}

Tabel 2.2. Perbedaan antara tiga uji deteksi LTBI (Dyrhol-Riise et al., 2010)

\subsection{Sel $T-\gamma \delta$}

Sel $\mathrm{T}-\gamma \delta$ adalah sel yang mengekspresikan reseptor TCR rantai $\gamma \delta$. Di darah tepi, poplasi mereka sangatlah sedikit, yaitu 1\%-5\%, tetapi sangatlah banyak di jaringan epital dan mukosa, misalnya rongga mulut, saluran cerna, saluran nafas, dan saluran reproduksi. Di saluran cerna, jumlah sel $\mathrm{T}-\gamma \delta$ dapat melebihi 50\% dari total Limfosit intraepitel (Itohara et al., 1990. Gertner et al., 2007). Pada awalnya sel $\mathrm{T}-\gamma \delta$ mengikuti jalur maturasi utama sel $\mathrm{T}$, tetapi setelah haematophoietic stem cells (HSCs) menerima sinyal delta-like 4-mediated notch, HSCs menjadi progenitor sel $\mathrm{T}$ yaitu double negative atau $\mathrm{CD}^{-} \mathrm{CD} 8^{-}(\mathrm{DN})$. Pada tahapan DN2, sebuah tipe sel akan keluar dari jalur maturasi utama dan menjadi sel T- $\gamma \delta$. Hingga kini, mekanismenya masih belum jelas, tetapi ada dugaan bahwa hal tersebut tergantung pada kekuatan sinyal pre-TCR, apakah lebih kuat TCR $\alpha \beta$ yang nantinya menjadi sel Th, sel Tc, dan sel Treg, atau TCR $\gamma \delta$ yang nantinya menjadi sel T$\gamma \delta$ (Shibata., 2012). 


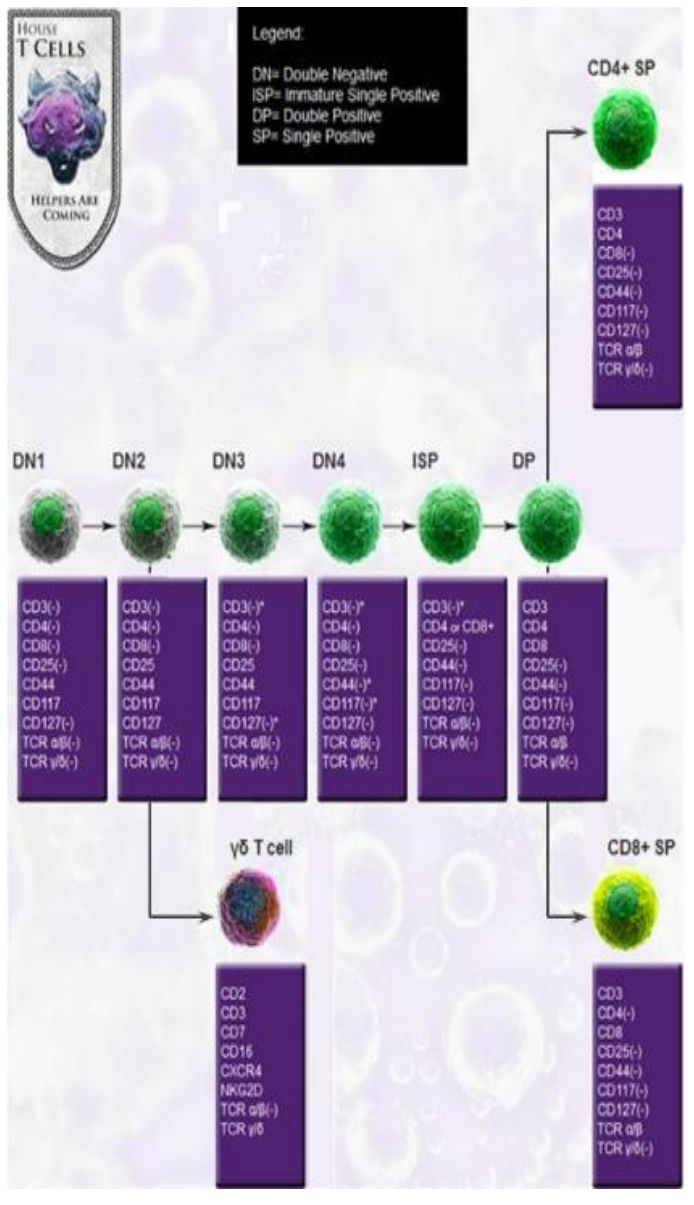

Gambar 2.1. Proliferasi dan Maturasi sel T (Biolegend.com)

Serupa TCR $\alpha \beta, \quad T C R \gamma \delta$ adalah reseptor heterodimer yang tersusun dari dua subnit glikoprotein, yaitu rantai $\gamma 30 \mathrm{kDa}-$ $60 \mathrm{kDa}$ dan rantai $\delta 40 \mathrm{kDa}-60 \mathrm{kDa}$. Komposisi dan Stoikiometri CD3 yang diekspresikan oleh sel T- $\alpha \beta$ dan sel T- $\gamma \delta$ adalah sama. Mereka berisi enam subunit $\mathrm{CD} 3(\gamma, \delta, 2 \varepsilon, 2 \zeta)$ yang membentuk homodimer atau heterodimer. Interaksi antara rantai TCR dan kompleks CD3 dimulai melalui suatu ikatan transmembran TCR $\gamma$ dan $\delta$ serta subunit CD3 $\gamma$ dan CD $3 \delta$. Sementara, sinyal dibawah oleh CD3 $\varepsilon$ dan CD3ל. Berdasarkan repertoire, lokus $\gamma$ terletak di kromosom 7, berisi dua segmen gen constant $(\mathrm{C} \gamma 1$ dan $\mathrm{C} \gamma 2)$, lima elemen joining (J $\gamma 1 \mathrm{~S} 1, \mathrm{~J} \gamma 1 \mathrm{~S} 2, \mathrm{~J} \gamma 1 \mathrm{~S} 3$, J $\gamma 2 \mathrm{~S} 1$, dan $\mathrm{J} \gamma 2 \mathrm{~S} 2$ ), dan empat belas gen variable yang terbagi dalam empat kelompok (Gertner et al., 2007).
Pada saat teraktivasi, sel $\mathrm{T}-\gamma \delta$ menjadi dua subtipe, yaitu sel $\mathrm{T}-\gamma \delta$-IFN $\gamma$ memproduksi IFN- $\gamma$ dan sel T- $\gamma \delta-$ IL-17 yang memproduksi IL-17. Sinyal Skint-1 diperlukan untuk aktivasi sel tersebut menjadi sel $\mathrm{T}-\gamma \delta$-IFN $\gamma$, tetapi belum diketahui apakah mutlak diperlukan atau tidak. Ketiadaan sinyal tersebut menyebabkan kehilangan fungsi produksi IFN- $\gamma$ dan berubah menjadi penghasil IL-17 (SeL T- $\gamma \delta$-IL-17). Sementara, sinyal Notch1 bersama protein Hes1 dapat mengativasi sel tersebut menjadi sel T- $\gamma \delta$-IL-17. Di Samping itu, IL-23 mutlak diperlukan guna aktivasi sel $\mathrm{T}-\gamma \delta$ subtipe ini (Jensen et al., 2008. turcinovich and hayday., 2011).

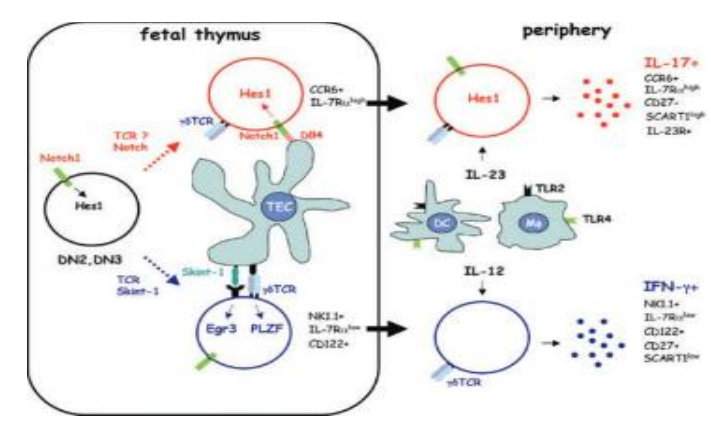

Gambar 2.3. Aktivasi sel T- $\gamma \delta$ (Shibata., 2012)

Sel T- $\gamma \delta$ sangatlah khas dalam menge-nali antigen karena dapat bertindak sebagai MHC-restricted maupun non-MHC-restricted. Secara umum, sel T$\gamma \delta$ mengenali golongan phosphoantigens yang dilepas oleh sel hidup, bakteri, tanaman, bahkan sel kanker. Secara khusus, sel $\mathrm{T}-\gamma \delta$ mengenali enterotoxin $\mathrm{A}$, Ig rantai ringan $\gamma$, glikoprotein herpes simplex virus (HSV), MICA, MICB, HSPs, tetanus toxoid, T10, dan T22. Keanekaragaman tersebut tidak terlepas dari bentuk lekukan antigen-binding TCR $\gamma \delta$ lebih mirip bentuk lekukan antigen-binding Ig sehingga sel $\mathrm{T}-\gamma \delta$ mampu mengenali Epitop pada molekul native yang tidak mampu dikenali oleh sel imun lainnya (O'Brien et al., 1989. Gertner et al., 2007).

Pada umumnya, kebanyakan sel T- $\gamma \delta$ memproduksi IFN- $\gamma$, sitokin yang terlibat 
dalam imunitas protektif melawan M.tb. Kadar IFN- $\gamma$ pun lebih tinggi daripada yang diproduksi oleh sel imun lainnya, seperti sel Th1 maupun sel Tc. IFN- $\gamma$ yang diproduksi oleh sel $\mathrm{T}-\gamma \delta$ dirangsang oleh produksi IL-12 oleh makrofag atau sel dendrit selama infeksi. Selain itu, adanya IL-15 ternyata membantu sel $\mathrm{T}-\gamma \delta$ untuk menjadi sel memori yang tahan terhadap kematian sel (Caccamo et al., 2005. Cassetti and Martino., 2008). Sementara, IL-17 berperan penting dalam imunitas protektif melawan M.tb segera setelah infeksi maupun pada fase kronis (LTBI). Ternyata, Kadar IL-17 yang diproduksi oleh sel $\mathrm{T}-\gamma \delta$ lebih tinggi daripada yang diproduksi oleh sel Th17. Peranan sitokin tersebut adalah meningkatkan migrasi neutrofil meskipun bukan suatu kemokin. Karena itulah, sel $\mathrm{T}-\gamma \delta$ diyakini terlibat dalam pembentukan granuloma akibat IL-17 yang diproduksi dan neutrofil yang terpengaruh oleh IL-17 (L o c k har t et al., 2006. Umemura et al., 2007).

Tidak hanya pada infeksi M.tb, sel T$\gamma \delta$ berperan di kebanyakan infeksi bakteri, seperti Escherichia coli, Klebsiella pneumoniae, Listeria monocytogenes, dan Salmonella enterica. Pada pneumonia yang disebabkan oleh Klebsiella pneumoniae dan infeksi akibat Listeria monocytogenes, sel $\mathrm{T}-\gamma \delta$ adalah penghasil IFN- $\gamma$ di hari kedua setelah infeksi. Pada infeksi ini, produksi IFN- $\gamma$ tidak bergantung pada keberadaan IL-12 atau sinyal yang diperantarai TCR $\gamma \delta$. Pada beberapa infeksi, IL-23 bahkan dapat merangsang sel T$\gamma \delta$-IFN $\gamma$, padahal IL-23 adalah perangsang untuk sel T- $\gamma \delta$-IL-17. Peran IL-17 yang diproduksi oleh sel tersebut adalah sama di semua infeksi, yaitu merangsang migrasi neutrofil ke lokasi infeksi. Selain memproduksi sitokin, sel $\mathrm{T}-\gamma \delta$ dapat berperan sebagai APCs layaknya sel dendrit untuk T10 dan T22, sel pembunuh layaknya sel Tc melalui sitotoksisitas, bahkan sanggup menjadi regulator menggantikan peran sel Treg, tetapi pada imunitas innate (Shibata., 2012).
Selain berperan dalam infeksi, sel $\mathrm{T}-\gamma \delta$ juga terlibat dalam aktivitas protumor dan antitumor. Hal tersebut karena metabolit mevalonate pada sel-sel kanker dapat merangsang sel $\mathrm{T}-\gamma \delta$. Sel $\mathrm{T}-\gamma \delta$ memiliki reseptor sama seperti sel NK, yaitu natural killer group 2 member $D$ protein $(N K G 2 D)$ yang berfungsi untuk mengenali sel tumor. Ikatan antara ligan dan reseptor NKG2D akan menghasilkan $\mathrm{TNF} \alpha$, meningkatkan ekspresi IL-2R $\alpha$, dan aktivitas sitolitik melalui MICA, MICB, dan ULBP yang diekspresikan oleh beberapa jenis sel kanker, misalnya leukemia, lymphoma, dan kanker ovarium (Gober et al., 2003. Gorgoi and Chiplunkar., 2013). IL-17 yang diproduksi oleh sel T- $\gamma \delta$ ternyata memiliki efek ganda, yaitu protumor dan antitumor. Protumor karena dapat merangsang ekspresi growth reglates oncogene- $\alpha$ (GRO- $\alpha$ ) dan IL-8. Kedua kemokin tersebut berperan dalam angiogenesis dimana dapat meningkatkan proliferasi dan survival sel kanker. Antitumor karena IL-17 dapat merangsang produksi IL-6 dan IL-12. Kedua sitokin tersebut berperan dalam mengaktivasi sel Tc spesifik tumor (Moore et al., 1998. Murugaiyan and Saha., 2009).

\section{Bahan dan Metode}

Jenis penelitian ini adalah observasional analisis dengan rancangan penelitian adalah case and control study. Ada dua kelompok subyek penelitian, yaitu kelompok TB dan LTBI, dimana dengan besar sampel masing-masing adalah 10, sehingga besar sampel yang digunakan keseluruhan adalah 20 . Semua subyek didapatkan dari Rumah Sakit Paru Surabaya melalui persetujuan etik dari Universitas Airlangga. Sementara itu, bahan-bahan yang digunakan antara lain anti-CD3-PerCP, anti-TCR $\gamma \delta$-FITC, larutan cytofix/ cytoperm, larutan phosphate buffer saline $(P B S)$, dan larutan staining. Dalam penelitian ini dilakukan dua tahapan, yaitu tahap preparasi sampel dan tahap pewarnaan antibodi. Pada tahap preparasi sampel, sampel darah di- 
tambahkan larutan PBS, dihomogenkan, diletakkan di kamar gelap, dilakukan sentrifugasi, dan pembuangan supernatan. Tahap pewarnaan sampel dimulai dengan penambahan anti-CD3-PerCP dan anti-TCR $\gamma \delta$-FITC, larutan staining, dilakukan sentrifugasi, pembuangan supernatan, larutan cytofix/cytoperm, dan diletakkan di kamar gelap. Setelah selelsai semua tahapan, maka sampel siap untuk dilakukan penghitungan dengan piranti FACSCalibur.

Dalam mendapatkan subyek, dilakukan pemilihan kriteria terlebih dahulu sebab terdapat kriteria inklusi dan ekslusi. Kriteria inklusi adalah kriteria yang harus dipenuhi sebagai syarat agar subyek menjadi sampel sesuai yang telah ditetapkan. Sementara kriteria ekslusi adalah kriteria yang dalam keadaan normalnya dapat masuk ke kriteria inklusi, tetapi oleh karena ada hal tertentu subyek tidak dapat dijadikan untuk sampel penelitian, misalnya adalah menderita penyakit tertentu atau keadaan tertentu yang dipastikan dapat mempengaruhi hasil penelitian. Saat calon subyek telah didapatkan, maka mereka harus membubuhkan tanda tangan di sebuah lembar persetujuan untuk melakukan tindakan (informed consent) di depan peneliti dan disaksikan oleh seorang saksi yang telah ditunjuk sebelumnya sebagai tanda bersedia ikut serta sebagai subyek penelitian.

\section{H a s i l}

Hasil penelitian menunjukkan bahwa perbandingan jenis kelamin pada kedua kelompok adalah seimbang, yaitu 50\% pada laki-laki dan $50 \%$ pada perempuan. Sementara, berdasarkan jumlah sel $\mathrm{T}-\gamma \delta$ pada kelompok TB lebih merata di semua rentang usia dibandingkan pada kelompok LTBI yang lebih banyak di usia di atas 30 tahun hingga 50 tahun. Berdasarkan hasil uji deskriptif didapatkan rerata jumlah sel $\mathrm{T}-\gamma \delta$ pada kelompok TB adalah $10,6944 \% \quad \pm$ $3,7714 \%$ dengan nilai minimum $6,07 \%$ dan nilai maksimum $17,51 \%$, sedangkan jumlah sel T- $\gamma \delta$ pada kelompok LTBI adalah $15,4222 \% \pm 2,3007 \%$ dengan nilai minimum $11,05 \%$ dan nilai maksimum $18,25 \%$.

\begin{tabular}{|c|c|c|c|c|}
\hline Kelompok & Rerata & S. Baku & Minimum & Maximum \\
\hline TB & 10,6944 & 3,7714 & 6,07 & 17,51 \\
\hline LTBI & 15,4222 & 2,3007 & 11,05 & 18,25 \\
\hline
\end{tabular}

Tabel 4.1. Hasil uji deksriptif jumlah sel T$\gamma \delta$

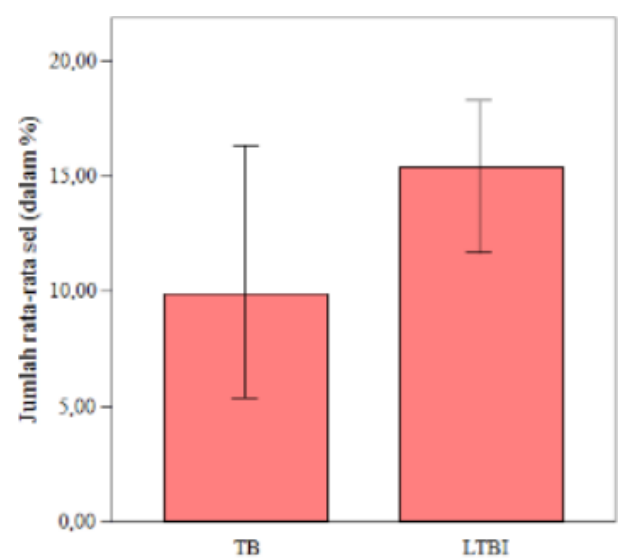

Gambar 4.1. Jumlah rata-rata sel T- $\gamma \delta(\%)$

Dalam hasil uji normalitas, data hasil penelitian ini adalah berdistribusi normal dimana nilai $\mathrm{P}$ adalah 0,745 untuk kelompok TB dan 0,607 untuk kelompok LTBI. Kedua kelompok tersebut menunjukkan bahwa nilai $\mathrm{P}>0,05$ dan dapat dilanjutkan dengan uji homogenitas. Hasil uji homogenitas menunjukkan bahwa data hasil penelitian ini adalah homogen dimana nilai $\mathrm{P}$ adalah $0,118(\mathrm{P}>0,05)$. Karena data hasil penelitian ini adalah homogen, maka untuk uji t dua kelompok menunjukkan bahwa nilai $\mathrm{P}$ adalah 0,005. Hasil uji $\mathrm{t}$ dua kelompok menunjukkan bahwa nilai $\mathrm{P}<$ 0,05, berarti terdapat Signifikansi.

\begin{tabular}{|c|c|c|}
\hline Kelompok & df & Sig. \\
\hline TB & 9 & 0,745 \\
\hline LTBI & 9 & 0,607 \\
\hline
\end{tabular}

Tabel 4.2. Uji normalitas (Shapiro-Wilk) 


\begin{tabular}{|c|c|}
\hline Variabel & Sig. \\
\hline Jumlah sel T- $\gamma \delta$ & 0,118 \\
\hline Tabel 4.3. Uji homogenitas (Uji Levene)
\end{tabular}

\begin{tabular}{|c|c|c|}
\hline & df & Sig. \\
\hline Homogen & 16 & 0,005 \\
\hline Tidak homogen & 13,230 & 0,007 \\
\hline
\end{tabular}

Tabel 4.4. Uji t dua kelompok

Pada contoh hasil flowcytometry terdapat empat kuadran, yaitu UL (upperleft), UR (upper-right), LL (lower-left), dan LR (lower-right). Untuk mengetahui jumlah sel $\mathrm{T}-\gamma \delta$, kita harus mengetahui bahwa karakteristik sel tersebut adalah sel $\mathrm{T}$ dengan TCR rantai $\gamma \delta$, maka kuadran mereka adalah UR karena menunjukkan anti-CD3 bernilai positif (mewakili sel $\mathrm{T}$, terletak di atas sumbu X), dan anti-TCR $\gamma \delta$ (+) (mewakili TCR $\gamma \delta$, terletak di kanan sumbu Y). Sementara nilai yang tertera di sudut setiap kuadran tersebut adalah jumlah total sel (dalam \%) yang menunjukkan karakteristik setiap kuadran. Karena sel T- $\gamma \delta$ berada di kuadran UR, maka jumlah sel tersebut yang terhitung dalam metode flowcytometry adalah 9,50\%. 9,50\% menunjukkan bahwa jumlah sel T- $\gamma \delta$ bila dibandingkan dengan sel lain di darah tepi adalah 9,50\%. Nilai tersebut lebih Tinggi dari jumlah normal $(1 \%-5 \%)$.

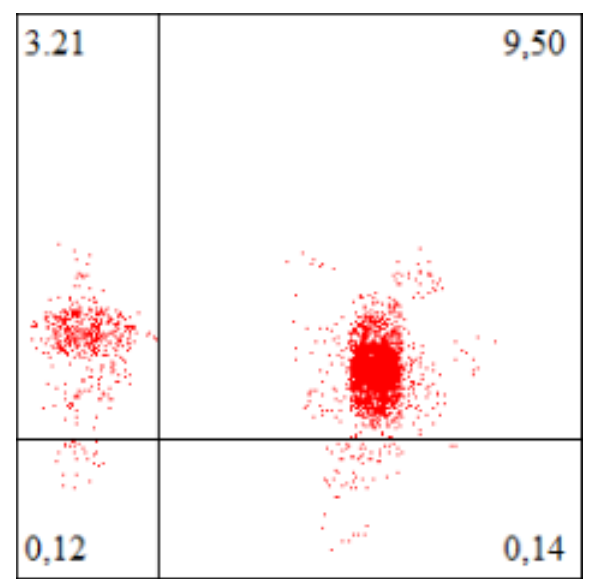

Gambar 4.2. Salah satu hasil flowcytometry 5. Pembahasan
TB dan LTBI disebabkan oleh bakteri yang sama, yaitu bacilli M.tb. Tetapi yang membedakan keduanya adalah ada atau tidaknya gejala. Pada TB sangat tampak sekali gejala disertai penampilan fisik penderita, sedangkan pada LTBI tidak ada gejala dan orang dengan LTBI tampak sehat secara fisik dan mental. Selain itu, belum diketahui apakah ada perbedaan dengan jumlah sel-sel imun yang terlibat dalam TB dan LTBI. Maka, hasil penelitian ini diharapkan dapat mengungkap semua misteri tentang jumlah sel $\mathrm{T}-\gamma \delta$ beserta peranannya pada infeksi tuberkulosis terutama pada LTBI.

Hasil penelitian ini menunjukkan bahwa jumlah sel T- $\gamma \delta$ pada TB dan LTBI mengalami peningkatan. Jumlah sel $\mathrm{T}-\gamma \delta$ pada TB mencapai rerata $10,7 \%$ atau sekitar 5\% lebih tinggi dari nilai normal (1\%-5\%). Sementara, jumlah sel $\mathrm{T}-\gamma \delta$ pada LTBI justru lebih mengejutkan lagi. Mereka mencapai rerata $15,4 \%$ atau sekitar $10 \%$ lebih tinggi dari nilai normal (1\%-5\%) dan sekitar 5\% lebih tinggi dari jumlah sel T- $\gamma \delta$ pada TB. Itu adalah sesuatu yang mengejutkan karena selama ini LTBI diasumsikan sebagai kondisi 'normal' karena orang dengan LTBI tampak normal. Selain itu, terdapat satu hal lagi yang menjadi ambiguitas dalam penelitian ini, yaitu tingginya jumlah sel T$\gamma \delta$ pada salah satu penderita TB yang hampir menyamai jumlah sel $\mathrm{T}-\gamma \delta$ pada salah satu orang dengan LTBI. Hal tersebut disebabkan penderita TB tersebut sedang dalam masa pemulihan.

Masuknya patogen ke dalam tubuh host pasti memicu respons imun yang ditandai dengan meningkatnya jumlah selsel imun yang terlibat. Berdasarkan banyak penelitian yang telah dilakukan sebelum-nya, meningkatnya jumlah sel $\mathrm{T}-\gamma \delta$ pada TB disebabkan melimpahnya kadar IL-12 yang diproduksi oleh makrofag dan sel dendrit. IL-12 dapat merangsang aktivasi sel $\mathrm{T}-\gamma \delta$ menjadi sel $\mathrm{T}-\gamma \delta$-IFN- $\gamma$ yang memproduksi IFN- $\gamma$. Sitokin tersebut berperan untuk memperkuat makrofag terinfeksi agar mampu membunuh M.tb yang berada di dalamnya dan mengaktivasi makrofag tidak 
terinfeksi agar siaga terhadap bakteri intraseluler tersebut. Bila siklus ini berlangsung selama infeksi, tentunya jumlah sel T- $\gamma \delta$ juga ikut meningkat.

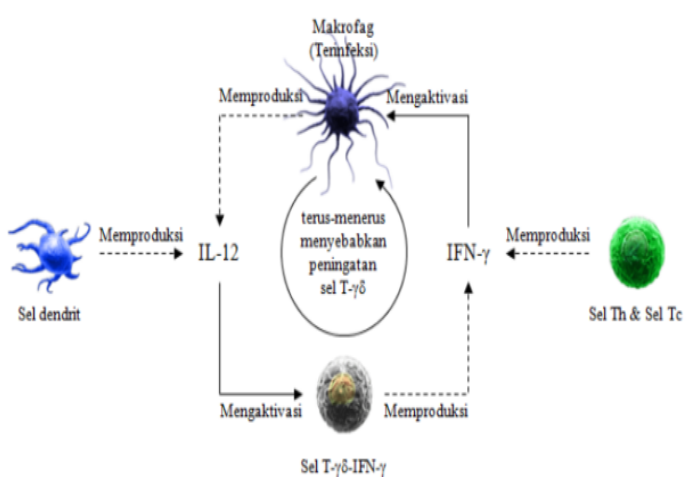

Gambar 5.1. Peranan sel T- $\gamma \delta$ pada TB

Meningkatnya jumlah sel T- $\gamma \delta$ pada LTBI hingga kini belum ditemukan alasan pasti, karena belum ada penelitian sebelumnya. Hasil penelitian ini menunjukkan bahwa jumlah sel $\mathrm{T}-\gamma \delta$ pada LTBI melebihi jumlah sel $\mathrm{T}-\gamma \delta$ pada TB yang notabene adalah sedang mengalami infeksi. Akan menjadi sesuatu yang mengejutkan bila tidak ada infeksi tetapi jumlah sel imun terjadi peningkatan tajam. Pada LTBI ini diasumsikan karena banyaknya HSPs yang dilepas oleh M.tb di bawah kondisi stres. HSPs sendiri merupakan salah satu ligan yang dapat dikenali oleh sel $\mathrm{T}-\gamma \delta$, sehingga tidak heran apabila jumlah sel tersebut mengalami meningkatan. Meskipun demikian, masih menyisakan suatu pertanyaan tentang bagaimana cara dan HSPs dilepas oleh M.tb serta bagaimana cara sel $\mathrm{T}-\gamma \delta$ dapat diaktivasi oleh HSPs.

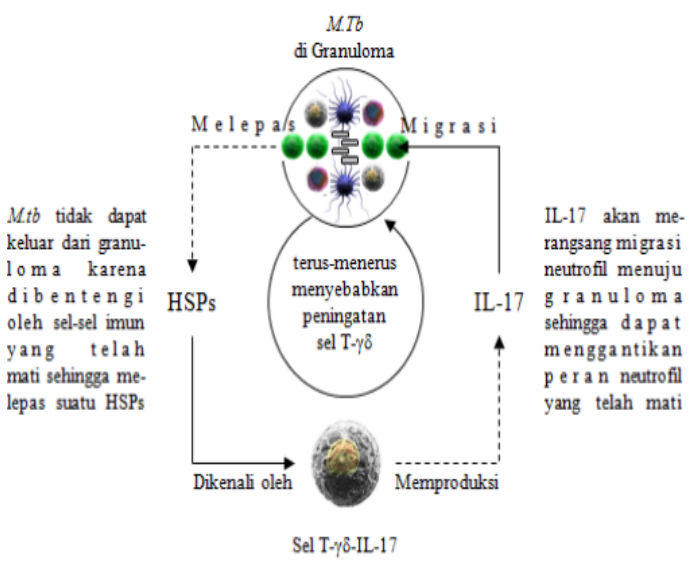

Gambar 5.2. Peranan sel T- $\gamma \delta$ pada LTBI

Pada LTBI, M.tb terkurung di dalam granuloma yang berisi sel-sel imun yang telah mati, baik karena fisiologis (apoptosis) maupun patologis (nekrosis). Peranan sel $\mathrm{T}-\gamma \delta$ diasumsikan adalah menjadi sel T- $\gamma \delta$-IL-17 yang memproduksi IL-17. IL-17 tersebut merangsang migrasi neutrofil ke granuloma. Neutrofil migrasi ke granuloma tidak lain adalah menggantikan peran makrofag sebagai pembersih sisa-sisa sel-sel yang telah mati karena makrofag di granuloma pada umumnya telah terinfeksi oleh M.tb dan membentuk sel epiteloid atau menjadi sel sabun tanpa kemampuan fagositosis. Selain menggantikan peran makrofag, neutrofil juga melakukan immunosurveillance menggantikan neutrofil sesamanya yang telah mati. Karena usia neutrofil pendek, maka pasti memerlukan sel $\mathrm{T}-\gamma \delta$ yang mampu memproduksi IL-17 selama-lamanya, mengingat LTBI hingga kini belum dapat disembuhkan. Oleh karena itulah, wajar apabila jumlah sel $\mathrm{T}-\gamma \delta$ pada orang dengan LTBI menunjukkan peningkatan yang sangat tinggi. Hal tersebut dikarenakan host masih memerlukan sel T- $\gamma \delta$-IL-17 agar M.tb dapat dikontrol dan menyeimbangkan sistem imunitas. Namun demikian, ini masih sebatas asumsi, masih memerlukan studi atau penelitian lebih lanjut mengenai hubungan antara HSPs, sel T- $\gamma \delta$, neutrofil, dan LTBI.

\section{Simpulan}


Dari hasil penelitian ini dapat kita simpulkan, yaitu :

1. Terdapat perbedaan yang signifikan antara jumlah sel $\mathrm{T}$ subset gammadelta di darah tepi pada penderita tuberkulosis dan orang dengan latent tuberculosis infection.

2. Terjadi peningkatan yang besar jumlah sel $\mathrm{T}$ subset gamma-delta pada orang dengan latent tuberculosis infection, dimana selama ini banyak yang beranggapan bahwa orang dengan LTBI adalah orang sehat, sehingga jumlah sel-sel imun pun diasumsikan normal. Penelitian ini menbuktikan tidak demikian.

\section{Daftar Pustaka}

赤川清子 [Akagawa K]. 2012. 結核の免疫 [Imunitas Tuberkulosis]. Kekkaku, 2: 61-70.

Briken V, Porcelli SA, Besra GS, Kremer L. 2004. Mycobacterial Lipoarabinomannan and Related Lipoglycans: from Biogenesis to Modulation of the Immune Response. Mol. Microbiol, 35: 391-403.

Caccamo N, Meraviglia S, Ferlazzo V et al. 2005. Differential Requirement for Antigen of Homeostatic Cytokine for Proliferation and Differentiation of Human $\mathrm{V} \gamma 9 \mathrm{~V} \delta 2$ Naive, Memory, and Effector $\mathrm{T}$ Cell Subsets. Eur. J. Immunol, 35: 1764-1772.

Cassetti R, Martino A. 2008. The Plasticity of Gamma-Delta T Cells: Innate Immunity, Antigen Presentation, and New Immunotherapy. Cell. Mol. Immunol, 5: 161-170.

Chan J, Flynn JL. 2004. The Immunological Aspects of Latency in Tuberculosis. Clin. Immunol, 110: 2-12.

Derrick SC, Morris SL. 2007. The ESAT-6 Protein of Mycobacterium tuberculosis Induces Apoptosis of Macrophages by Activating Capsase Expression. Cell. Microbiol, 9: 1547-1555.

Co DO, Hogan LH, Kim SI, Sandor M. 2004. Mycobacterial Granulomas: Keys to a Long-Lasting Host-Pathogen

Relationship. Clin. Immunol, 113: 130-136.

Druszczynska M, Kowalewich0Kulbat M, Pol M, Wlodarczyk M, Rudnicka W. 2012. Latent $M$. tuberculosis Infection Pathogenesis, Diagnosis, Treatment, and Prevention Strategies. PJM, 61: 3-10.

Dye C, Scheele S, Dolin P, Pathania V, Raviglione MC. 1999. Consensus Statement. Global Burden of Tuberculosis: Estimated Insidence, Prevalence, and Mortality by County. JAMA, 282: 677-686.

Dyrhol-Riise AM, Gran G, Wentzel-Larsen T, Bloomberg B, Haanshuus CG, Morkve O. 2010. Diagnosis and Follow-up of Treatment of Latent Tuberculosis: The Utility of the QuantiFERON TB Gold inTube Assay in Outpatients Form a Tuberculosis Low-Endemic Country. BMC. Infect. Dis, 10: 57-65.

Gertner J, Scotet M, Poupot M, Bonneville M, Fournie JJ. 2007. Lymphocytes: Gamma-Delta. In: Roitt's Essential Immunology, $12^{\text {th }}$ Edition. Encyclopedia of Life Science. pp. 1-10. Available in: www.roitt.com/elspdf/lymphocytes_gamma _delta.pdf.

Gideon HP, Flynn JL. 2011. Latent Tuberculosis: What the Host 'Sees'? Immunol. Res, 50: 202-212.

Gober HJ, Kistowska M, Angman L, Jeno P, Mori L, de Libero G. 2003. Human T Cell Receptor Gammadelta $\mathrm{T}$ Cells Recognize Endogenous Mevalonate Metabolites in Tumor Cells. J. Exp. Med, 197: 163-168.

Gogoi D, Chiplunkar SV. 2013. Targeting Gamma-Delta $T$ Cells for Cancer Immunotherapy: Bench to Bedside. IJMR, 138: 755-761.

Grosset J. 2003. Mycobacterium tuberculosis in the Extracellular Compartment: an Underestiated Adversary. 
Antimicrob. Agents. Chemother, 47: 833836.

Hanekom WA, Mendillo M, Manca C et al. 2003. Mycobacterium tuberculosis Inhibits Maturation of Human Monocyte-Derived Dendritic Cells in Vitro. J. Infect. Dis, 188: 257-266.

Hartmann P, Becker R, Franzen C et al. 2001. Phagocytosis and Killing of Mycobacterium avium Complex by Human Neutrophils. J. Leuko. Bio, 69: 397-404.

Itohara S, Farr AG, Lafaille JJ, Bonneville M, Takagaki Y, Haas W, Tonegawa S. 1990. Homing of Gamma-Delta Thymocyte Subset with Homogenous T-Cell Receptors to Mucosal Epithelial. Nature, 343: 754-757.

Jensen KD, Su X, Shin S et al. 2008. Thymic Selection Determines GammaDelta T Cell Effector Fate: Antigen-Naive Cells Make Interleukin-17 and AntigenExperienced Cells Make Interferon Gamma. Immunity, 29: 90-100.

Junqueira-Kipnis AP, Kipnis A, Jamieson A, Juarerro MG, Diefenbach A, Raulet DH, Turner J, Orme IM. 2003. NK Cells Respond to Pulmonary Infection with Mycobacterium tuberculosis, but Play a Minimal Role in Protection. J. Immunol, 171: 6039-6045.

Kaufmann SHE. 2012. Mycobacterium tuberculosis: Success Through Dormancy. FEMS. Microbiol. Rev, 36: 514-532.

Kawai T, Akira S. 2010. The Role of Pattern-Recognition Receptors in Innate Immunity: Update on Toll-like Receptors. Nat. Rev. Immun, 11: 373-384.

Kinhikar AG, Verma I, Chandra D et al. 2010. Potential Role for ESAT-6 in Dissemination of $M$. tuberculosis via Human Lung Epithelial Cells. Mol. Microbiol, 75: 92-106.
Means TK, Wang S, Lien E, Yoshimura A, Golenbock DT, Fenton MJ. 1999. Human Toll-like Receptors Mediate Cellular Activation by Mycobacterium tuberculosis. J. Immunol, 163: 3920-3927.

Murugaiyan G and Saha B. 2008. Protumor vs Antitumor Function of IL-17. $J$. Immunol, 183: 4169-4175.

O'Brien RL, Happ MP, Dallas A, Palmer E, Kubo R, Born WK. 1989. Stimulation of a Major Subset of Lymphocytes Expressing T Cell Receptor Gamma-Delta by an Antigen Derived from Mycobacterium tuberculosis, Cell, 57: 667-674.

Ogata K, Linzer BA, Zuberi RI, Ganz T, Lehrer RI, Catanzaro A. 1992. Activity of Defensins from Human Neutrophilic Granulocytes Againts Mycobacterium avium - Mycobacterium intracellulare. Infect Immun, 60: 4720-4725.

Peyron P, Vaubourgeix J, Poquet Y et al. 2008. Foamy Macrophages from Tuberculosis Patients Granulomas Constitute a Nutrient-Rich Reservoir for M. tuberculosis Persistence. PLoS. Pathog, 4: 100204.

Serbina NV, Lazarevic V, Flynn JL. 2001. CD4+ $\mathrm{T}$ Cells are Required for the Development of Cytotoxic CD8+ T Cells during Mycobacterium tuberculosis Infection. J. Immunol, 167: 6991-7000.

Shibata K. 2012. Close Link Between Development and Function of GammaDelta T Cells. Microbiol. Immunol, 56: 217-227.

Turcinovich G, Hayday AC. 2011. Skint-1 Identifies a Common Molecular Mechanism for the Development of Interferon-Gamma-Secreting versus Interlekin-17-Secreting Gamma-Delta $\mathrm{T}$ Cells. Immunity, 35: 59-68.

Umemura M, Yahagi A, Hamada S, Watanabe H, Kawakami K, Suda T, Sudo K, Nakae S, Iwakra Y, Matsuzaki G. 2007. IL-17-Mediated Regulation of Innate and 
Jurnal Biosains Pascasarjana Vol. 18 (2016) pp

(C) (2016) Sekolah Pascasarjana Universitas Airlangga, Indonesia

Acquired Immune Response Againts Pulmonary Mycobacterium bovis Bacillus Calmette-Guerin Infection. J. Immunol, 178: 3786, 3796.

WHO. 2015. Global Tuberculosis Report. Genewa: World Health Organization. pp. 1134. Available in: http://www.who.int/tb/publications/global_r eport/gtbr15_main_text.pdf. 